\title{
Composition and volumes of slurry in soybean seeds treatment in the industry and physiological quality during storage ${ }^{1}$
}

\author{
Sheyla Ferreira dos Santos ${ }^{2}$, Everson Reis Carvalho ${ }^{3 *}$, \\ Debora Kelli Rocha ${ }^{4}$, Rodrigo Marques Nascimento ${ }^{5}$
}

\begin{abstract}
Seeds treatment is a relevant factor in the soybean production system. The aim of this work was to evaluate composition and volumes of slurry used in industrial treatment of soybean seeds, and their physiological quality during storage. The experimental design was completely randomized, in a 20x4 factorial scheme, i.e. 20 seeds treatments and four storage periods $(0,30,90$ and 150 days). Seeds of the cultivars NS7667IPRO and NS7709IPRO were used. The slurry composition tested were a combination of fungicide and insecticide Standak top ${ }^{\circledR}$ (Fipronil + Piraclostrobin + Thiophanate Methyl), polymer L551Incotec ${ }^{\circledR}$ and water, in order to obtain the volumes of 450, 700 and $1200 \mathrm{~mL} .100 \mathrm{~kg}$ of seeds ${ }^{-1}$, and the controls treatment. The physiological quality was assessed by germination in sand and accelerated aging tests. Genotypes showed distinct tolerance to seed treatment industrial, slurry volumes and storage. Treatments with Standak top ${ }^{\circledR}$, polymer and water, with volumes of up to $1200 \mathrm{~mL} .100 \mathrm{~kg} \mathrm{seed}^{-1}$, and stored for 150 days in cold chamber were not harmful for germination of cultivar NS7667IPRO. As for cultivar NS7709IPRO, the tolerance was 90 days. Treating seeds with large slurry volumes is detrimental to maintain seeds vigor during storage, with depreciation after 30 days, especially with water predominance.
\end{abstract}

Index terms: Fipronil + Pyraclostrobin + Thiophanate-methyl, Glycine max, seed treatment, STI, vigor.

\section{Constituições e volumes de calda no tratamento industrial de sementes de soja e a qualidade fisiológica durante o armazenamento}

\begin{abstract}
RESUMO - O tratamento de sementes é um fator relevante no sistema produtivo da soja. O objetivo neste trabalho foi avaliar as constituições e volumes de calda no tratamento industrial de sementes de soja sobre a qualidade fisiológica no armazenamento. $\mathrm{O}$ delineamento foi inteiramente casualizado, fatorial 20x4, com 20 tratamentos de sementes e quatro períodos de armazenamento ( 0 ; 30; 90 e 150 dias). Utilizou-se sementes das cultivares NS7667IPRO e NS7709IPRO. As caldas foram combinações de fungicida e inseticida Standak top ${ }^{\circledR}$ (Fipronil + Piraclostrobina + Tiofanato Metílico), polímero L551Incotec ${ }^{\circledR}$ e água para obtenção dos volumes: 450,700 e $1200 \mathrm{~mL} .100 \mathrm{~kg}$ de sementes ${ }^{-1}$, e controles sem tratamentos. A qualidade fisiológica foi avaliada com a germinação em areia e envelhecimento acelerado. Os genótipos apresentam tolerâncias distintas ao tratamento industrial, volumes de calda e armazenamento. O armazenamento de sementes tratadas, com volumes de até $1200 \mathrm{~mL} .100 \mathrm{~kg}$ sementes ${ }^{-1}$, por 150 dias em câmara fria não ocasionou prejuízos à germinação de sementes da cultivar NS7667IPRO. Para a cultivar NS7709IPRO, a viabilidade foi mantida por 90 dias de armazenamento. $\mathrm{O}$ tratamento de sementes com volume de calda elevado é prejudicial para a manutenção do vigor das sementes ao longo do armazenamento, com depreciação aos 30 dias, principalmente com predominância aquosa da calda.
\end{abstract}

Termos para indexação: Fipronil + Piraclostrobina + Tiofanato Metílico, Glycine max, TSI, tratamento de semente, vigor.

\section{Introduction}

Soybean culture contributes significantly to Brazilian exports. In the 2016/2017 crop, it occupied an area of 33.9 million hectares, which accounted for $30.9 \%$ of worldwide production (CONAB, 2017). In order to sustain this growth,

${ }^{4}$ Universidade Federal de Uberlândia, UFU, 38400-902 - Uberlândia, MG, Brasil.

${ }^{5}$ Engenheiro Agrônomo, 38700-222 - Patos de Minas, MG, Brasil.

*Corresponding author <ercarvalho@ufu.br>

\footnotetext{
${ }^{1}$ Submitted on 09/15/2017. Accepted for publication on 11/29/2017.

${ }^{2}$ Instituto Federal do Triângulo Mineiro, 38064-300 - Uberaba, MG, Brasil. ${ }^{3}$ Universidade Federal de Uberlândia, UFU, Instituto de Ciências Agrárias, 38500-000 - Monte Carmelo, MG, Brasil.
}

\footnotetext{
*orresponding author<ercarvalho@ufu.br $>$
}

Journal of Seed Science, v.40, n.1, p.067-074, 2018 
it is necessary to adopt innovations in the production system and to introduce new technologies to boost production, and many of them are propagated through seeds. In this sense, seed producer companies have been adopting seeds treatment in the industry (Ferreira et al., 2016).

In this process, seeds are treated in the beneficiation line, and then they are bagged and stored until the moment of sowing. However, the industrial treatment of seeds may present some limiting factors, such as negative effects that the active ingredients might cause on seeds during storage, and later in field (Brzezinski et al., 2015). Dan et al. (2010) reported that seeds treated with certain insecticides exhibited a negative interference with the physiological quality throughout the storage, a fact also identified by Piccicin et al. (2013).

In addition to the active ingredient applied, the quality of the treatment depends on the final composition of the material used, on the application rate on the seeds, and on seeds physical and physiological quality (ABRASEM, 2017). The slurry volume may be composed of a variety of products and combinations of fungicides, insecticides, nematicides, growth regulators, micronutrients, inoculants, and also colorants, pigments and polymers. The use of different compounds in the industrial treatment of seeds may result in a high volume of slurry, capable of exceeding $600 \mathrm{~mL} .100 \mathrm{of} \mathrm{kg}$ of seed ${ }^{-1}$, the maximum volume indicated for treatment of seeds via liquid, without damaging them (EMBRAPA, 2011). Thus, there are several possibilities of composition and volumes of slurry for treatment of seeds, and studies on their relationship with the physiological quality of seeds are necessary.

According to Bays et al. (2007), coating soybean seeds with fungicide, micronutrients and polymer provided them with good appearance, adherence, distribution and coloration. They reported that, even though the maximum limit of slurry volume was maintained $\left(600 \mathrm{~mL} .100 \mathrm{~kg}\right.$ of seeds $\left.\mathrm{s}^{-1}\right)$, a phytotoxic effect was observed when the slurry was rich in micronutrient (400 mL.100 kg of seed $\left.{ }^{-1}\right)$. Not only the final volume is relevant, but also the constitution of the slurry affects the physiological quality of seeds.

A component that may favor the constitution of the slurry is the polymer, whether in liquid or in powder forms. In works combining fungicides and polymers, Pereira et al. (2007) and Pereira et al. (2011) reported that the polymers did not affect the physiological quality of the seeds and promoted a better adhesion of the fungicides. In both studies, the final volume of slurry did not exceed $500 \mathrm{~mL} .100 \mathrm{~kg}$ of seed ${ }^{-1}$. Despite advantageous, coating seeds may negatively affect their physiological quality throughout storage, as observed by Avelar et al. (2011), when polymer in powder was used in soybean seeds.

Nowadays, in view of the number of compounds and products that can be combined and applied in the seeds, and of the search for better coating and distribution, it is necessary to use higher volumes of slurry. The use of larger volumes of slurry in the treatment without causing consequences to the physiological quality of soybean seeds depends on several factors, such as the vigor. The determination of the ideal final volume, which does not affect the physiological quality of seeds, is extremely important, especially considering the effects that may occur throughout seeds storage (Segalin et al., 2013; Pereira et al., 2016; Brzezinski et al., 2017).

Therefore, the objective in this study was to evaluate the effects of composition, components (separately or in combination), and volumes of slurry used in the industrial treatment of seeds of soybean cultivars on the physiological quality of the seeds during storage under controlled conditions.

\section{Material and Methods}

The experiment was carried out at the Laboratory of seed analysis of Nidera Sementes, located in Patos de Minas, state of Minas Gerais (MG), Brazil, in a collaboration with the Universidade Federal de Uberlândia (UFU) and the Instituto Federal do Triângulo Mineiro (IFTM). Seeds of two soybean cultivars were selected according to their initial characteristics of germination and vigor. For the decision-making process, the following tests were performed:

Moisture content: according to the Rules for Seed Testing in Brazil (Brasil, 2009). Tetrazolium test: seeds were preconditioned on Germitest moistened paper for a period of 16 hours at $25{ }^{\circ} \mathrm{C}$. After preconditioning, the seeds were immersed in $0.075 \%$ tetrazolium solution, in which they remained for 3 hours at $40^{\circ} \mathrm{C}$, in a dark environment (França-Neto et al., 1998). Germination in sand: it was used trays containing 5 kilograms of sand moistened with $50 \%$ of its retention capacity as substrate. The seeds were sow, covered with a $1 \mathrm{~cm}$ layer of sand, and then placed into the germinators, under 24 hours of light, at the controlled temperature of $25^{\circ} \mathrm{C}$, for a period of five days. For the evaluation of the samples, abnormal and normal seedlings were considered, according to the criteria established by the Rules for Seed Testing (Brasil, 2009). Accelerated aging: adapted gerboxes filled with $40 \mathrm{~mL}$ of water were used. Seeds were deposited in a single layer on the screen, and the boxes with lid were placed in a BOD chamber at $41{ }^{\circ} \mathrm{C}$ for 48 hours (Marcos-Filho, 2005). After this period, the seeds were submitted to the germination test with sand substrate, as previously described, and the results were expressed as percentage of normal seedlings (Brasil, 2009).

After the initial characterization of the lots, due to the similarity of the parameters analyzed, a lot of seeds of the cultivar NS7667IPRO and a lot of seeds of the cultivar 
NS7709IPRO, crop 2015/2016, produced in the same region were used. At the time of the treatment, the seeds of the cultivars NS7667IPRO and NS7709IPRO had 10.0\% and $10.2 \%$ moisture content, respectively. Seeds treatment was performed in July 2016, when lots of $3 \mathrm{~kg}$ were processed in an Arktus Africa ${ }^{\circledR}$ machine, fabricated by Momesso, in order to simulate an treatment process in the industry (STI or TSI). The composition of the slurries for treatment were elaborated involving fungicide and insecticide Standak top ${ }^{\circledR}$ (Fipronil + Pyraclostrobin + Thiophanate-methyl) in commercial dose, polymer L551 Incotec ${ }^{\circledR}$, and water, in association or in isolated form, to obtain the final volumes of slurry: 450,700 or 1200 $\mathrm{mL} .100 \mathrm{~kg}$ of seed ${ }^{-1}$. Two control treatments were also used: untreated seeds (Control 1), and seeds treated only with the phytosanitary product (Standak top ${ }^{\circledR}$ : Fipronil + Pyraclostrobin + Thiophanate-methyl) at the time of the tests (Control 2). Variations of the slurry composition are described in Table 1.

After the treatment, seeds were left in the shade to dry, at approximately $20^{\circ} \mathrm{C}$, for 20 minutes. Then, they were packed in multiwall Kraft paper and stored in cold chamber, with temperature controlled at $11.5^{\circ} \mathrm{C}$ and relative humidity at $54 \%$, in the city of Patos de Minas, MG, Brazil. The samples were separated to be analyzed after $0,30,90$ and 150 days of storage. The moisture content was monitored throughout storage. The physiological quality of the seeds during storage was assessed by the tests of germination in sand and accelerated aging, as previously described, with four replications of 50 seeds.

The design was completely randomized, in a 20x4 factorial scheme, involving 20 industrial seed treatments and four storage periods $(0,30,90$ and 150 days), with four replications. Analyzes were performed independently for each cultivar (NS7667IPRO and NS7709IPRO). The data were submitted to analysis of variance using the Sisvar ${ }^{\circledR}$ software (Ferreira, 2014), at $5 \%$ probability by the F-test, and the means were grouped by Scott-Knott test $(\mathrm{p}<0.05)$.

\section{Results and Discussion}

In the germination in sand and vigor assessed by the accelerated aging test, according to the analysis of variance, a significant effect was observed for all sources of variation, seed treatment and storage, in isolated manner, and with significant interaction in both cultivars. The moisture levels did not differ statistically. In seeds of cultivar NS7667IPRO, values ranged from 8.9 to $10.9 \%$, and the mean was $9.8 \%$. In the cultivar NS7709IPRO, values ranged from 8.6 to $10.4 \%$, and the mean was $9.6 \%$. The coefficients of variation stayed between $3.4 \%$ and $10.1 \%$, which reflects the precision in the

Table 1. Composition and volumes of slurry $\left(\mathrm{mL} .100 \mathrm{~kg}_{\text {of sementes }}{ }^{-1}\right)$ used in seeds treatment in the industry (STI) with the phytosanitary product Standak Top ${ }^{\circledR}$, the polymer L $551^{\circledR}$ and water.

\begin{tabular}{|c|c|c|c|c|c|}
\hline \multirow{2}{*}{ Initials } & \multirow{2}{*}{ Seeds treatment in the industry } & \multicolumn{4}{|c|}{ mL. $100 \mathrm{~kg}^{-1}$ of seeds } \\
\hline & & Standak Top ${ }^{\circledR}$ & Polymer & Water & Total \\
\hline $\mathrm{C}+1 \mathrm{~W}$ & Chemical + Dose 1 water & 200 & 0 & 250 & 450 \\
\hline $\mathrm{C}+1 \mathrm{P}$ & Chemical + Dose 1 polymer & 200 & 250 & 0 & 450 \\
\hline $\mathrm{C}+1 \mathrm{WP}$ & Chemical + Dose 1 ( $50 \%$ water $/ 50 \%$ poly mer $)$ & 200 & 125 & 125 & 450 \\
\hline $\mathrm{NC}+1 \mathrm{~W}$ & No chemical + Dose 1 water & 0 & 0 & 450 & 450 \\
\hline $\mathrm{NC}+1 \mathrm{P}$ & No chemical + Dose 1 polymer & 0 & 450 & 0 & 450 \\
\hline $\mathrm{NC}+1 \mathrm{WP}$ & No chemical + Dose $1(50 \%$ water $/ 50 \%$ polymer $)$ & 0 & 225 & 225 & 450 \\
\hline $\mathrm{C}+2 \mathrm{~W}$ & Chemical + Dose 2 water & 200 & 0 & 500 & 700 \\
\hline $\mathrm{C}+2 \mathrm{P}$ & Chemical + Dose 2 polymer & 200 & 500 & 0 & 700 \\
\hline $\mathrm{C}+2 \mathrm{WP}$ & Chemical + Dose $2(50 \%$ water $/ 50 \%$ poly mer $)$ & 200 & 250 & 250 & 700 \\
\hline $\mathrm{NC}+2 \mathrm{~W}$ & No chemical + Dose 2 water & 0 & 0 & 700 & 700 \\
\hline $\mathrm{NC}+2 \mathrm{P}$ & No chemical + Dose 2 polymer & 0 & 700 & 0 & 700 \\
\hline $\mathrm{NC}+2 \mathrm{WP}$ & No chemical + Dose $2(50 \%$ water $/ 50 \%$ polymer $)$ & 0 & 350 & 350 & 700 \\
\hline $\mathrm{C}+3 \mathrm{~W}$ & Chemical + Dose 3 water & 200 & 0 & 1000 & 1200 \\
\hline $\mathrm{C}+3 \mathrm{P}$ & Chemical + Dose 3 polymer & 200 & 1000 & 0 & 1200 \\
\hline $\mathrm{C}+3 \mathrm{WP}$ & Chemical + Dose 3 ( $50 \%$ water $50 \%$ poly mer) & 200 & 500 & 500 & 1200 \\
\hline $\mathrm{NC}+3 \mathrm{~W}$ & No chemical + Dose 3 water & 0 & 0 & 1200 & 1200 \\
\hline $\mathrm{NC}+3 \mathrm{P}$ & No chemical + Dose 3 polymer & 0 & 1200 & 0 & 1200 \\
\hline $\mathrm{NC}+3 \mathrm{WP}$ & No chemical + Dose 3 ( $50 \%$ water/ $50 \%$ polymer) & 0 & 600 & 600 & 1200 \\
\hline $\mathrm{C} 2$ & No STI during storage and STI at the moment of the tests & 200 & 0 & 0 & 200 \\
\hline $\mathrm{C} 1$ & No Seed Treatment in the Industry (STI) & 0 & 0 & 0 & 0 \\
\hline
\end{tabular}


conduction of the experiments.

In cultivar NS7667IPRO seeds, all treatments, regardless of the combination, presented values of germination in sand above $82 \%$ (Table 2 ).

In seeds not treated with the phytosanitary chemical (Table 2) with fungicide and insecticidal action, an increase in the germination values in the first periods of storage was verified. The lowest values observed at the beginning of storage period may be related to the absence of fungicide action in the initial analysis. Similar results were observed by Carvalho et al. (2014), who reported an increase in the percentage of germination of soybean seeds stored for up to 92 days, a fact that is inherent to the reduction of incidence of field fungi in stored seeds.

Therefore, when seeds treatments were compared before storage (day zero), most of the treatments that had been designated to the group that showed lowest germination did not have phytosanitary chemicals (NC) in the slurry, especially when the largest volume was used, $1200 \mathrm{~mL} .100$ $\mathrm{kg}$ of seed $^{-1}$ (Table 2).

Table 2. Mean percentage of germination in sand, as a function of the seeds treatments in the industry and of the storage periods in cold chamber, cultivar NS7667IPRO.

\begin{tabular}{|c|c|c|c|c|}
\hline \multirow{2}{*}{ Seeds treatment } & \multicolumn{4}{|c|}{ Storage period (days) } \\
\hline & 0 & 30 & 90 & 150 \\
\hline $\mathrm{C}+1 \mathrm{~W}$ & $94 \mathrm{Aa}$ & $97 \mathrm{Aa}$ & $96 \mathrm{Aa}$ & $96 \mathrm{Aa}$ \\
\hline $\mathrm{C}+1 \mathrm{P}$ & $95 \mathrm{Aa}$ & $96 \mathrm{Aa}$ & $92 \mathrm{Bb}$ & $89 \mathrm{Bb}$ \\
\hline $\mathrm{C}+1 \mathrm{WP}$ & $92 \mathrm{Bb}$ & $89 \mathrm{Bb}$ & $96 \mathrm{Aa}$ & $95 \mathrm{Aa}$ \\
\hline $\mathrm{NC}+1 \mathrm{~W}$ & $91 \mathrm{Bb}$ & $96 \mathrm{Aa}$ & $93 \mathrm{Bb}$ & $97 \mathrm{Aa}$ \\
\hline $\mathrm{NC}+1 \mathrm{P}$ & $94 \mathrm{Ba}$ & $93 \mathrm{Ba}$ & $98 \mathrm{Aa}$ & $98 \mathrm{Aa}$ \\
\hline $\mathrm{NC}+1 \mathrm{WP}$ & $89 \mathrm{Bb}$ & $98 \mathrm{Aa}$ & $91 \mathrm{Bb}$ & $93 \mathrm{Bb}$ \\
\hline $\mathrm{C}+2 \mathrm{~W}$ & $90 \mathrm{Ab}$ & $93 \mathrm{Aa}$ & $95 \mathrm{Aa}$ & $95 \mathrm{Aa}$ \\
\hline $\mathrm{C}+2 \mathrm{P}$ & $95 \mathrm{Aa}$ & $95 \mathrm{Aa}$ & $91 \mathrm{Bb}$ & $91 \mathrm{Bb}$ \\
\hline $\mathrm{C}+2 \mathrm{WP}$ & $91 \mathrm{Bb}$ & $95 \mathrm{Aa}$ & $95 \mathrm{Aa}$ & $98 \mathrm{Aa}$ \\
\hline $\mathrm{NC}+2 \mathrm{~W}$ & $93 \mathrm{Ba}$ & $96 \mathrm{Aa}$ & $92 \mathrm{Bb}$ & $98 \mathrm{Aa}$ \\
\hline $\mathrm{NC}+2 \mathrm{P}$ & $89 \mathrm{Bb}$ & $99 \mathrm{Aa}$ & $91 \mathrm{Bb}$ & $97 \mathrm{Aa}$ \\
\hline $\mathrm{NC}+2 \mathrm{WP}$ & $91 \mathrm{Bb}$ & $96 \mathrm{Aa}$ & $95 \mathrm{Aa}$ & $91 \mathrm{Bb}$ \\
\hline $\mathrm{C}+3 \mathrm{~W}$ & $95 \mathrm{Aa}$ & $93 \mathrm{Aa}$ & $90 \mathrm{Ab}$ & $92 \mathrm{Ab}$ \\
\hline $\mathrm{C}+3 \mathrm{P}$ & $84 \mathrm{Cc}$ & $96 \mathrm{Aa}$ & $97 \mathrm{Aa}$ & $90 \mathrm{Bb}$ \\
\hline $\mathrm{C}+3 \mathrm{WP}$ & $92 \mathrm{Ab}$ & $82 \mathrm{Bc}$ & $94 \mathrm{Ab}$ & $96 \mathrm{Aa}$ \\
\hline $\mathrm{NC}+3 \mathrm{~W}$ & $90 \mathrm{Bb}$ & $90 \mathrm{Bb}$ & $95 \mathrm{Aa}$ & $93 \mathrm{Ab}$ \\
\hline $\mathrm{NC}+3 \mathrm{P}$ & $91 \mathrm{Ab}$ & $95 \mathrm{Aa}$ & $94 \mathrm{Aa}$ & $91 \mathrm{Ab}$ \\
\hline $\mathrm{NC}+3 \mathrm{WP}$ & $89 \mathrm{Bb}$ & $91 \mathrm{Bb}$ & $92 \mathrm{Bb}$ & $98 \mathrm{Aa}$ \\
\hline $\mathrm{C} 2$ & $94 \mathrm{Aa}$ & $96 \mathrm{Aa}$ & $96 \mathrm{Aa}$ & $92 \mathrm{Ab}$ \\
\hline $\mathrm{C} 1$ & $95 \mathrm{Aa}$ & $95 \mathrm{Aa}$ & $97 \mathrm{Aa}$ & $94 \mathrm{Aa}$ \\
\hline
\end{tabular}

*Means followed by the same lowercase letter in the column and by the same uppercase letter in the row do not differ from each other by Scott-Knott test at $5 \%$ probability.
Still about the cultivar NS7667IPRO, at the end of the storage period of 150 days in cold room, all treatments exhibited germination rate above $89 \%$, even the seeds treated with larger volumes of slurry. With the highest volume of slurry $\left(1200 \mathrm{~mL} .100 \mathrm{~kg}_{\text {of seed }}{ }^{-1}\right)$, regardless of the use of the chemical, the combination of polymer and water resulted in a higher germination than when these components were used in isolated form (Table 2).

In cultivar NS7709IPRO seeds, a depreciation of germination occurred after 150 days of storage, reaching $38 \%$, even under controlled conditions. Thus, it is possible to infer that the storage of treated seeds, even in cold rooms, for 150 days is not adequate for this genotype. On the other hand, after 90 days of storage, germination above $85 \%$ was observed in all treatments (Table 3). For Pereira et al. (2016), although seeds treatments up to $1800 \mathrm{~mL} .100 \mathrm{~kg}$ of seed ${ }^{-1}$ had caused a decrease in the physiological potential of soybeans seeds, even after 60 days of conventional storage all of them presented germination means above $80 \%$, the minimum germination standard for commercialization (MAPA, 2013).

Table 3. Mean percentage of germination in sand, as a function of the seeds treatments in the industry and of the storage periods in cold chamber, cultivar NS7709IPRO.

\begin{tabular}{ccccc}
\hline \multirow{2}{*}{ Seeds treatment } & \multicolumn{4}{c}{ Storage period (days) } \\
\cline { 2 - 5 } $\mathrm{C}+1 \mathrm{~W}$ & $89 \mathrm{Aa}$ & $91 \mathrm{Aa}$ & $93 \mathrm{Aa}$ & $88 \mathrm{Ab}$ \\
$\mathrm{C}+1 \mathrm{P}$ & $92 \mathrm{Aa}$ & $84 \mathrm{Bb}$ & $98 \mathrm{Aa}$ & $82 \mathrm{Bc}$ \\
$\mathrm{C}+1 \mathrm{WP}$ & $89 \mathrm{Ba}$ & $96 \mathrm{Aa}$ & $95 \mathrm{Aa}$ & $85 \mathrm{Bc}$ \\
\hline $\mathrm{NC}+1 \mathrm{~W}$ & $82 \mathrm{Bb}$ & $84 \mathrm{Bb}$ & $94 \mathrm{Aa}$ & $92 \mathrm{Ab}$ \\
$\mathrm{NC}+1 \mathrm{P}$ & $89 \mathrm{Aa}$ & $94 \mathrm{Aa}$ & $94 \mathrm{Aa}$ & $89 \mathrm{Ab}$ \\
$\mathrm{NC}+1 \mathrm{WP}$ & $94 \mathrm{Aa}$ & $88 \mathrm{Ab}$ & $87 \mathrm{Ab}$ & $91 \mathrm{Ab}$ \\
\hline $\mathrm{C}+2 \mathrm{~W}$ & $86 \mathrm{Bb}$ & $88 \mathrm{Bb}$ & $95 \mathrm{Aa}$ & $94 \mathrm{Aa}$ \\
$\mathrm{C}+2 \mathrm{P}$ & $90 \mathrm{Aa}$ & $86 \mathrm{Ab}$ & $91 \mathrm{Ab}$ & $38 \mathrm{Bf}$ \\
$\mathrm{C}+2 \mathrm{WP}$ & $81 \mathrm{Bb}$ & $88 \mathrm{Ab}$ & $91 \mathrm{Ab}$ & $81 \mathrm{Bc}$ \\
$\mathrm{NC}+2 \mathrm{~W}$ & $91 \mathrm{Ba}$ & $89 \mathrm{Ba}$ & $97 \mathrm{Aa}$ & $86 \mathrm{Bc}$ \\
$\mathrm{NC}+2 \mathrm{P}$ & $87 \mathrm{Ab}$ & $93 \mathrm{Aa}$ & $88 \mathrm{Ab}$ & $52 \mathrm{Be}$ \\
$\mathrm{NC}+2 \mathrm{WP}$ & $88 \mathrm{Ba}$ & $92 \mathrm{Aa}$ & $87 \mathrm{Bb}$ & $96 \mathrm{Aa}$ \\
\hline $\mathrm{C}+3 \mathrm{~W}$ & $91 \mathrm{Aa}$ & $92 \mathrm{Aa}$ & $93 \mathrm{Aa}$ & $96 \mathrm{Aa}$ \\
$\mathrm{C}+3 \mathrm{P}$ & $79 \mathrm{Bb}$ & $77 \mathrm{Bc}$ & $85 \mathrm{Bb}$ & $95 \mathrm{Aa}$ \\
$\mathrm{C}+3 \mathrm{WP}$ & $88 \mathrm{Aa}$ & $90 \mathrm{Aa}$ & $91 \mathrm{Ab}$ & $89 \mathrm{Ab}$ \\
$-\mathrm{NC}+3 \mathrm{~W}$ & $93 \mathrm{Aa}$ & $91 \mathrm{Aa}$ & $97 \mathrm{Aa}$ & $80 \mathrm{Bc}$ \\
$\mathrm{NC}+3 \mathrm{P}$ & $92 \mathrm{Aa}$ & $86 \mathrm{Bb}$ & $95 \mathrm{Aa}$ & $62 \mathrm{Cd}$ \\
$\mathrm{NC}+3 \mathrm{WP}$ & $82 \mathrm{Bb}$ & $89 \mathrm{Ab}$ & $92 \mathrm{Ab}$ & $63 \mathrm{Cd}$ \\
$-\mathrm{C} 2$ & $84 \mathrm{Bb}$ & $95 \mathrm{Aa}$ & $94 \mathrm{Aa}$ & $95 \mathrm{Aa}$ \\
$\mathrm{C} 1$ & $85 \mathrm{Bb}$ & $96 \mathrm{Aa}$ & $97 \mathrm{Aa}$ & $89 \mathrm{Bb}$ \\
\hline---1 & &
\end{tabular}

*Means followed by the same lowercase letter in the column and by the same uppercase letter in the row do not differ from each other by Scott-Knott test at $5 \%$ probability. 
In the first and second evaluation periods, the $\mathrm{C}+3 \mathrm{P}$ treatment (chemical + dose 3 polymer) was always assigned to the lowest germination group, and it was the only treatment with mean below $80 \%$, even with the predominance of viscous slurry, due to the polymer (Table 3 ). The exclusive use of the polymer at higher doses did not favor the maintenance of the physiological quality, since after 150 days of storage the lowest germination rates were observed in the $\mathrm{C}+2 \mathrm{P}$ (chemical + dose 2 polymer) and $\mathrm{NC}+2 \mathrm{P}$ (no chemical + dose 2 polymer) treatments. However, Pereira et al. (2007), when studying the effect of the polymer associated or not with fungicides, found a beneficial effect of this association in stored seeds.

After 150 days of storage, for the highest slurry dose $\left(1200 \mathrm{~mL} .100 \mathrm{~kg}\right.$ of $\left.\mathrm{seed}^{-1}\right)$, it was verified that in the treatments that the phytosanitary product, with fungicide and insecticide properties, Standak top ${ }^{\circledR}$ (Fipronil + Pyraclostrobin + Thiophanate-methyl) was used, the average germination was higher than in those treatments without the chemical product, at that dose. This demonstrates the positive effect of this product on preserving seeds quality, even after storage (Table 3). The use of large volumes of slurry in the treatment of seeds (1200 $\mathrm{mL} .100 \mathrm{~kg}$ of seed ${ }^{-1}$ ) may favor fungal proliferation and seeds deterioration. Therefore, the use of products with fungicidal action that do not present phytotoxic effect on the seeds can help maintain their quality throughout storage.

The relation between the use of phytosanitary products and the physiological quality can be verified by analyzing the control treatments after 150 days of storage. The control C1 (no chemical treatment) presented lower germination than the control C2 (no STI during storage, and STI at the moment of the test) (Table 3). Probably the fungicide/insecticide action favored seed viability in the germination test. The treatment with thiamethoxam favored the physiological potential of soybean seeds with high and medium vigor, stored for up to 30 days (Dan et al., 2013). According to Ferreira et al. (2016), the use of Standak top ${ }^{\circledR}$ (Fipronil + Pyraclostrobin + Thiophanatemethyl) provided negative effects on the quality of soybean seeds stored for two months under uncontrolled conditions.

In cultivar NS7667IPRO seeds, regarding the storage periods, vigor was lower in most seed treatment composition, up from 30 days of storage (Table 4). After 90 days, this effect was verified mainly in the largest volume of slurry. After 150 days of storage, there was a decrease in vigor in all treatments, except in the $\mathrm{C}+1 \mathrm{P}($ Chemical + dose 1 polymer $)$ and in the $\mathrm{NC}+1 \mathrm{P}(\mathrm{No}$ Chemical + dose 1 polymer $)$ ones, both with 450 $\mathrm{mL} .100 \mathrm{~kg}$ of seed ${ }^{-1}$. Piccinin et al. (2013), when studying soybean seeds treated with fipronil and thiamethoxan, verified a reduction in vigor after 180 days of storage. It is worth mentioning that the accelerated aging test exposes seeds to a high relative humidity and a high temperature, causing the products to concentrate, which may damage the membrane due to the penetration of the product, and trigger a phytotoxic effect that affects seed vigor (Pereira et al., 2007).

In the treatment $\mathrm{NC}+3 \mathrm{~W}$ (no chemical + dose 3 water), the decrease in vigor was prominent, and it reached $27 \%$ (Table 4) already after 30 days in cold chamber storage, which reiterates that the aqueous predominance in large volumes is not adequate for maintaining the vigor throughout storage. Untreated seeds are exposed to fungi attack during storage, thus suffering more deterioration in the accelerated aging test (Pereira et al., 2007). This is particularly true in this case, in which a large volume of aqueous slurry without phytosanitary product was used.

As for the different constitutions and slurry volumes, after 30 days of storage, the highest values of vigor were concentrated in slurry volumes of up to $700 \mathrm{~mL} .100 \mathrm{~kg}$ of seed $^{-1}$ and in the control $\mathrm{C} 1$. The lowest value obtained in the accelerated aging test was in the $\mathrm{NC}+3 \mathrm{~W}$ treatment (no chemical + dose 3 water) (Table 4 ), which also provided the

Table 4. Mean percentage of germination in sand, after the accelerated aging test, as a function of the seeds treatment in the industry and of the storage period in cold chamber, cultivar NS7667IPRO.

\begin{tabular}{|c|c|c|c|c|}
\hline \multirow{2}{*}{ Seeds treatment } & \multicolumn{4}{|c|}{ Storage period (days) } \\
\hline & 0 & 30 & 90 & 150 \\
\hline $\mathrm{C}+1 \mathrm{~W}$ & $77 \mathrm{Bb}$ & $85 \mathrm{Aa}$ & $82 \mathrm{Aa}$ & $70 \mathrm{Bb}$ \\
\hline $\mathrm{C}+1 \mathrm{P}$ & $75 \mathrm{Ab}$ & $79 \mathrm{Aa}$ & $80 \mathrm{Aa}$ & $70 \mathrm{Ab}$ \\
\hline $\mathrm{C}+1 \mathrm{WP}$ & $84 \mathrm{Aa}$ & $68 \mathrm{Bb}$ & $76 \mathrm{Ab}$ & $55 \mathrm{Cc}$ \\
\hline $\mathrm{NC}+1 \mathrm{~W}$ & $76 \mathrm{Ab}$ & $60 \mathrm{Bc}$ & $72 \mathrm{Ab}$ & $61 \mathrm{Bb}$ \\
\hline $\mathrm{NC}+1 \mathrm{P}$ & $83 \mathrm{Aa}$ & $74 \mathrm{Ba}$ & $84 \mathrm{Aa}$ & $86 \mathrm{Aa}$ \\
\hline $\mathrm{NC}+1 \mathrm{WP}$ & $82 \mathrm{Aa}$ & $81 \mathrm{Aa}$ & $72 \mathrm{Bb}$ & $67 \mathrm{Bb}$ \\
\hline $\mathrm{C}+2 \mathrm{~W}$ & $90 \mathrm{Aa}$ & $64 \mathrm{Bb}$ & $71 \mathrm{Bb}$ & $67 \mathrm{Bb}$ \\
\hline $\mathrm{C}+2 \mathrm{P}$ & $82 \mathrm{Aa}$ & $57 \mathrm{Bc}$ & $62 \mathrm{Bc}$ & $64 \mathrm{Bb}$ \\
\hline $\mathrm{C}+2 \mathrm{WP}$ & $77 \mathrm{Ab}$ & $61 \mathrm{Bc}$ & $79 \mathrm{Aa}$ & $65 \mathrm{Bb}$ \\
\hline $\mathrm{NC}+2 \mathrm{~W}$ & $72 \mathrm{Bb}$ & $63 \mathrm{Cb}$ & $86 \mathrm{Aa}$ & $53 \mathrm{Dc}$ \\
\hline $\mathrm{NC}+2 \mathrm{P}$ & $80 \mathrm{Aa}$ & $67 \mathrm{Bb}$ & $68 \mathrm{Bb}$ & $46 \mathrm{Dc}$ \\
\hline $\mathrm{NC}+2 \mathrm{WP}$ & $76 \mathrm{Ab}$ & $80 \mathrm{Aa}$ & $73 \mathrm{Ab}$ & $66 \mathrm{Bb}$ \\
\hline $\mathrm{C}+3 \mathrm{~W}$ & $72 \mathrm{Ab}$ & $66 \mathrm{Ab}$ & $61 \mathrm{Bc}$ & $56 \mathrm{Bc}$ \\
\hline $\mathrm{C}+3 \mathrm{P}$ & $77 \mathrm{Ab}$ & $52 \mathrm{Cc}$ & $66 \mathrm{Bc}$ & $52 \mathrm{Cc}$ \\
\hline $\mathrm{C}+3 \mathrm{WP}$ & $77 \mathrm{Ab}$ & $60 \mathrm{Bc}$ & $63 \mathrm{Bc}$ & $50 \mathrm{Cc}$ \\
\hline $\mathrm{NC}+3 \mathrm{~W}$ & $71 \mathrm{Ab}$ & $27 \mathrm{Bd}$ & $29 \mathrm{Bd}$ & $29 \mathrm{Bd}$ \\
\hline $\mathrm{NC}+3 \mathrm{P}$ & $65 \mathrm{Ab}$ & $69 \mathrm{Ab}$ & $56 \mathrm{Bc}$ & $50 \mathrm{Cc}$ \\
\hline $\mathrm{NC}+3 \mathrm{WP}$ & $76 \mathrm{Ab}$ & $70 \mathrm{Ab}$ & $74 \mathrm{Ab}$ & $63 \mathrm{Bb}$ \\
\hline $\mathrm{C} 2$ & $71 \mathrm{Bb}$ & $69 \mathrm{Bb}$ & $82 \mathrm{Aa}$ & $66 \mathrm{Bb}$ \\
\hline $\mathrm{C} 1$ & $68 \mathrm{Ab}$ & $73 \mathrm{Aa}$ & $59 \mathrm{Bc}$ & $59 \mathrm{Bb}$ \\
\hline
\end{tabular}

*Means followed by the same lowercase letter in the column and by the same uppercase letter in the row do not differ from each other by Scott-Knott test at $5 \%$ probability. 
lowest means in the periods subsequent to 30 days. Low mean values were also obtained with $\mathrm{C} 1$ (no chemical treatment), $\mathrm{C}+2 \mathrm{P}$ (chemical + dose 2 polymer), and most treatments with $1200 \mathrm{~mL} .100 \mathrm{~kg}$ of seed ${ }^{-1}$, after 90 days of storage. This trend was maintained until 150 days of storage, when seeds treated with the highest volume of slurry $(1200 \mathrm{~mL} .100 \mathrm{~kg}$ of seed $^{-1}$ ) presented low vigor. Segalin et al. (2013) reported the possibility of using slurry volumes of up to $1400 \mathrm{~mL} .100$ $\mathrm{kg}$ of seed $\mathrm{d}^{-1}$ without physical nor physiological losses to the seeds, but the storage was not considered.

In the cultivar NS7709IPRO seeds, treatments showed a reduction in vigor already after 30 days of storage, and a sharp decrease in vigor of seeds stored for 150 days, especially in the treatments with large slurry volume, $1200 \mathrm{~mL} .100 \mathrm{~kg}$ of seeds $^{-1}$ (Table 5).

In the initial analysis, the best values were obtained in the treatments $\mathrm{C}+1 \mathrm{~W}$ (chemical + dose 1 water), $\mathrm{NC}+1 \mathrm{P}$ (no chemical + dose 1 polymer) and $\mathrm{C}+2 \mathrm{~W}$ (chemical + dose 2 water), lower slurry volumes (Table 5). After 30 days, higher mean values of vigor were observed in the treatments $\mathrm{C} 1$ (Control 1) and $\mathrm{C}+1 \mathrm{P}$ (chemical + dose 1 polymer); the

Table 5. Mean percentage of germination in sand, after the accelerated aging test, as a function of the seeds treatment in the industry and of the storage period in cold chamber, cultivar NS7709IPRO.

\begin{tabular}{|c|c|c|c|c|}
\hline \multirow{2}{*}{ Seeds treatment } & \multicolumn{4}{|c|}{ Storage period (days) } \\
\hline & 0 & 30 & 90 & 150 \\
\hline$C+1 W$ & $79 \mathrm{Aa}$ & $66 \mathrm{Bc}$ & $83 \mathrm{Aa}$ & $68 \mathrm{Ba}$ \\
\hline $\mathrm{C}+1 \mathrm{P}$ & $68 \mathrm{Bb}$ & $78 \mathrm{Aa}$ & $83 \mathrm{Aa}$ & $65 \mathrm{Ba}$ \\
\hline $\mathrm{C}+1 \mathrm{WP}$ & $63 \mathrm{Ab}$ & $57 \mathrm{Bc}$ & $58 \mathrm{Bd}$ & $55 \mathrm{Bb}$ \\
\hline $\mathrm{NC}+1 \mathrm{~W}$ & $71 \mathrm{Ab}$ & $61 \mathrm{Bc}$ & $74 \mathrm{Ab}$ & $43 \mathrm{Cc}$ \\
\hline $\mathrm{NC}+1 \mathrm{P}$ & $85 \mathrm{Aa}$ & $59 \mathrm{Cc}$ & $75 \mathrm{Bb}$ & $66 \mathrm{Ca}$ \\
\hline $\mathrm{NC}+1 \mathrm{WP}$ & $66 \mathrm{Ab}$ & $68 \mathrm{Ab}$ & $69 \mathrm{Ab}$ & $65 \mathrm{Aa}$ \\
\hline $\mathrm{C}+2 \mathrm{~W}$ & $77 \mathrm{Aa}$ & $63 \mathrm{Bc}$ & $76 \mathrm{Ab}$ & $66 \mathrm{Ba}$ \\
\hline $\mathrm{C}+2 \mathrm{P}$ & $66 \mathrm{Ab}$ & $61 \mathrm{Ac}$ & $64 \mathrm{Ac}$ & $72 \mathrm{Aa}$ \\
\hline $\mathrm{C}+2 \mathrm{WP}$ & $64 \mathrm{Ab}$ & $64 \mathrm{Ac}$ & $53 \mathrm{Bd}$ & $53 \mathrm{Bb}$ \\
\hline $\mathrm{NC}+2 \mathrm{~W}$ & $73 \mathrm{Ab}$ & $67 \mathrm{Ab}$ & $66 \mathrm{Ac}$ & $39 \mathrm{Bc}$ \\
\hline $\mathrm{NC}+2 \mathrm{P}$ & $51 \mathrm{Bc}$ & $63 \mathrm{Ac}$ & $65 \mathrm{Ac}$ & $71 \mathrm{Aa}$ \\
\hline $\mathrm{NC}+2 \mathrm{WP}$ & $68 \mathrm{Ab}$ & $69 \mathrm{Ab}$ & $70 \mathrm{Ab}$ & $45 \mathrm{Bc}$ \\
\hline $\mathrm{C}+3 \mathrm{~W}$ & $63 \mathrm{Ab}$ & $66 \mathrm{Ac}$ & $62 \mathrm{Ac}$ & $37 \mathrm{Cc}$ \\
\hline $\mathrm{C}+3 \mathrm{P}$ & $71 \mathrm{Ab}$ & $59 \mathrm{Bc}$ & $60 \mathrm{Bc}$ & $54 \mathrm{Bb}$ \\
\hline $\mathrm{C}+3 \mathrm{WP}$ & $55 \mathrm{Ac}$ & $62 \mathrm{Ac}$ & $53 \mathrm{Bd}$ & $41 \mathrm{Bc}$ \\
\hline $\mathrm{NC}+3 \mathrm{~W}$ & $46 \mathrm{Ac}$ & $30 \mathrm{Bd}$ & $23 \mathrm{Be}$ & $22 \mathrm{Bd}$ \\
\hline $\mathrm{NC}+3 \mathrm{P}$ & $52 \mathrm{Bc}$ & $61 \mathrm{Ac}$ & $56 \mathrm{Ad}$ & $45 \mathrm{Bc}$ \\
\hline $\mathrm{NC}+3 \mathrm{WP}$ & $61 \mathrm{Ab}$ & $70 \mathrm{Ab}$ & $69 \mathrm{Ab}$ & $48 \mathrm{Bc}$ \\
\hline $\mathrm{C} 2$ & $65 \mathrm{Bb}$ & $61 \mathrm{Bc}$ & $75 \mathrm{Ab}$ & $62 \mathrm{Ba}$ \\
\hline $\mathrm{C} 1$ & $52 \mathrm{Cc}$ & $78 \mathrm{Aa}$ & $66 \mathrm{Bc}$ & $45 \mathrm{Cc}$ \\
\hline
\end{tabular}

*Means followed by the same lowercase letter in the column do not differ from each other by Scott-Knott test at $5 \%$ probability. seeds treated with larger volumes of slurry were classified as less vigorous, except for those treated with $\mathrm{NC}+3 \mathrm{WP}$ (no chemical + dose 3 water + polymer). Similar to what happened to cultivar NS7667IPRO, the $1200 \mathrm{~mL} .100 \mathrm{~kg} \mathrm{seed}^{-1}$ treatment with aqueous predominance provided the greatest deterioration of seeds throughout the storage.

After 90 days of storage, the treatments $\mathrm{C}+1 \mathrm{~W}$ (chemical + dose 1 water) and $\mathrm{C}+1 \mathrm{P}$ (chemical + dose 1 polymer $)$, both with $450 \mathrm{~mL} .100 \mathrm{~kg}$ of seed ${ }^{-1}$, showed higher vigor results. The same was observed after 150 days of storage (Table 5), which makes possible to infer that, for this genotype, when the intention is to store treated seeds, this final volume is the most adequate allied to the use of the phytosanitary product, so that the deterioration in vigor is low. As said by Vieira and Simonetti (2014), seeds treated with fipronil, even when stored for 60 days, showed no loss in vigor.

After 150 days, the treatments with $1200 \mathrm{~mL} .100 \mathrm{~kg}$ seed $^{-1}$ of slurry, regardless of the use of phytosanitary product, exhibited low vigor, always designated in the group of lower means (Table 5). This reinforces the deleterious effects of this volume of slurry on seeds vigor throughout storage. Brzezinski et al. (2017) reported a reduction in the physiological quality of low-vigor soybean seeds as a function of the increase in the volume of the slurry, up to $2400 \mathrm{~mL} .100 \mathrm{~kg}$ of seed ${ }^{-1}$, shortly after treatment, without storage of the treated seeds.

Thus, it was possible to observe that the volume and the composition of the slurry have a direct influence on the maintenance not only of the viability, but mainly on the vigor of soybean seeds throughout the storage, with different tolerances and behaviors between the genotypes. So, even if the storage conditions are adequate, it is important to choose the genotype properly, when treated seeds are to be stored, in order to maintain their physiological quality.

\section{Conclusion}

Tolerance to the industrial treatment, storage and maintenance of the physiological quality of soybean seeds are distinct between the genotypes.

In the cultivar NS7667IPRO, it is possible to store the seeds treated with Standak top ${ }^{\circledR}+$ polymer + water, with volumes of up to $1200 \mathrm{~mL} .100 \mathrm{~kg}$ seeds ${ }^{-1}$, for 150 days, in cold chamber, without damages to germination. In the cultivar NS7709IPRO, the viability was maintained for 90 days of storage, and later it decreased.

The treatment of seeds with a large volume of slurry can compromise the maintenance of seeds vigor throughout the storage, with depreciation after 30 days, especially if there is aqueous predominance in the slurry. 


\section{Acknowledgments}

To FAPEMIG - Fundação de Amparo à Pesquisa do Estado de Minas Gerais, Instituto Federal do Triângulo Mineiro (IFTM), Nidera Sementes and Universidade Federal de Uberlândia (UFU) for the infrastructure and financial support given to develop this work.

\section{References}

ABRASEM. Guia de boas práticas de tratamento de sementes. http://www.abrasem.com.br/wp-content/uploads/2014/12/Guia-TSIcompleto.pdf. Accessed on: 18 jun. 2017.

AVELAR, S.A.G.; BAUDET, L.; PESKE, S.T.; LUDWIG, M.P.; RIGO, G.A.; CRIZEL, R.L.; OLIVEIRA, S. Armazenamento de sementes de soja tratadas com fungicida, inseticida e micronutriente e recobertas com polímeros líquido e em pó. Ciência Rural, v.41, n.10, p.1719-1725, 2011. http://dx.doi.org/10.1590/S010384782011005000130

BAYS, R.; BAUDET, L.; HENNING, A. A.; LUCCA FILHO, O. Recobrimento de sementes de soja com micronutrientes, fungicida e polímero. Revista Brasileira de Sementes, v.29, n. 2, p. 60-67, 2007. http://www.scielo.br/pdf/rbs/v29n2/v29n2a09

BRASIL. Ministério da Agricultura, Pecuária e Abastecimento. Regras para análise de sementes. Ministério da Agricultura, Pecuária e Abastecimento. Secretaria de Defesa Agropecuária. Brasília: MAPA-ACS, 2009. 395p. http://www.agricultura.gov.br/arq_editor/ file/2946_regras_analise_sementes.pdf

BRZEZINSKI, C.R.; ABATI, J.; HENNING, F.A.; HENNING, A.A.; FRANÇA-NETO, J.B.; KRZYZANOWSKI, F.C.; ZUCARELI, C. Spray volumes in the industrial treatment on the physiological quality of soybean seeds with different levels of vigor. Journal of Seed Science, v.39, n.2, p.174-181, 2017. http://dx.doi.org/10.1590/2317$1545 \mathrm{v} 39 \mathrm{n} 2175179$

BRZEZINSKI, C.R.; HENNING, A.A.; ABATI, J.; HENNING, F.A.; FRANÇA-NETO, J.B.; KRZYZANOWSKI, F.C.; ZUCARELI, C. Seeds treatment times in the establishment and yield performance of soybean crops. Journal of Seed Science, v. 37, p. 147-153, 2015. http://dx.doi.org/10.1590/2317-1545v37n2148363

CARVALHO, E.R.; MAVAIEIE, D.P.R.; OLIVEIRA, J.A.; CARVALHO, M.V.; VIEIRA, A.R. Alterações isoenzimáticas em sementes de cultivares de soja em diferentes condições de armazenamento. Pesquisa Agropecuária Brasileira, v.49, n.12, p.96776, 2014. http://dx.doi.org/10.1590/S0100-204X2014001200007

CONAB - Companhia Nacional de Abastecimento. Acompanhamento da safra brasileira de grãos 2016/2017: sexto levantamento, 2017. http:// www.conab.gov.br/OlalaCMS/uploads/arquivos/17_03_09_09_16_09_ boletim graos_marco 2017.pdf Acesso em: 18 de jun. 2017.

DAN, L.G.M.; DAN, H.A.; BARROSO, A.L.L.; BRACCINI, A.L. Qualidade fisiológica de sementes de soja tratadas com inseticidas sob efeito do armazenamento. Revista Brasileira de Sementes, v. 32, n. 2, p. 131-139, 2010. http://www.scielo.br/pdf/rbs/v32n2/v32n2a16
DAN, L.G.M.; BRACCINI, A.L.; BARROSO, A.L.L.; DAN, H.A.; PICCININ, G.G.; VORONIAK, J.M. Physiological potential of soybean seeds treated with thiamethoxam and submitted to storage. Agricultural Sciences, v.4, n.11, p.19-25, 2013. http://file.scirp.org/ pdf/AS_2013112814020738.pdf

EMBRAPA. Tecnologias de produção de soja - região central do Brasil- 2012 e 2013. Accessed on: 18 jun 2017. https://www. infoteca.cnptia.embrapa.br/infoteca/bitstream/doc/904487/5/TEC. PROD.15.pdf

FERREIRA, D. F. Sisvar: a Guide for its Bootstrap procedures in multiple comparisons. Ciência e Agrotecnologia, v. 38, n.4, p.278286, 2014. http://dx.doi.org/10.1590/S1413-70542014000200001

FERREIRA, T.F.; OLIVEIRA, J.A.; CARVALHO, R.A.; RESENDE, L.S.; LOPES, C.G.M.; FERREIRA, V.F. Quality of soybean seeds treated with fungicides and insecticides before and after storage. Journal of Seed Science, v.38, n.4, p.278-286, 2016. http://dx.doi. org/10.1590/2317-1545v38n4161760

FRANÇA-NETO, J.B.; KRZYZANOWSKI, F.C.; COSTA, N.P. $O$ teste de tetrazólio em sementes de soja. Londrina: EMBRAPACNPSo, 1998. 72p. (Documentos, 116)

MAPA. Ministério da Agricultura, Pecuária e Abastecimento. Instrução Normativa $\mathrm{N}^{\circ} 45$, de 17 de setembro de 2013. Anexo XXIII - Padrões para produção e comercialização de sementes de soja. http://www.agricultura. gov.br/assuntos/insumos-agropecuarios/insumos-agricolas/sementes-emudas/publicacoes-sementes-e-mudas/INN45de17desetembrode2013. pdf Accessed on: Sep 27th , 2017.

MARCOS-FILHO, J. Fisiologia de sementes de plantas cultivadas. Piracicaba: FEALQ, 2005. 495p.

PEREIRA， C.E.; OLIVEIRA， J.A.; EVANGELISTA， J.R.E.; BOTELHO, F.J.E.; OLIVEIRA, G.E.; TRENTINI, P. Desempenho de sementes de soja tratadas com fungicidas e peliculizadas durante o armazenamento. Ciência e Agrotecnologia, v.31, n.3, p.656-665, 2007. http://dx.doi.org/10.1590/S1413-70542007000300009

PEREIRA, C. E.; OLIVEIRA, J. A.; GUIMARÃES, R. M.; VIEIRA, A. R.; EVANGELISTA, J. R. E.; OLIVEIRA, G. E. Tratamento fungicida e peliculização de sementes de soja submetidas ao armazenamento. Ciência e Agrotecnologia, v.35, n.1, p.158-164, 2011. http://dx.doi.org/10.1590/S1413-70542011000100020

PEREIRA, C.L.; GARCIA, M.M.; BRACCINI, A.L.; PIANA, S.C.; FERRI, G.C.; MATERA, T.C.; FELBER, P.H.; MARTELI, D.C.V. Efeito da adição de biorregulador ao tratamento industrial sobre a qualidade de sementes de soja (Glycine max (L.) Merr.) aos sessenta dias de armazenamento convencional. Revista Colombiana de investigaciones agroindustriales. v.3, n.2, p.15-22, 2016. http:// revistas.sena.edu.co/index.php/recia/article/view/347/pdf

PICCININ, G.G.; BRACCINI, A.L.; DAN, L.G.M.; BAZO, G.L.; LIMA, L.H.S. Influência do armazenamento na qualidade fisiológica de sementes de soja tratadas com inseticidas. Ambiência, v.9, n. 2, p.289 - 298, 2013. http://200.201.10.18/index.php/ambiencia/article/ view/1462 
SEGALIN, S.R.; BARBIERI, A.P.P.; HUTH, C.; BECHE, M.; MATTIONI, N.M.; MERTZ, L.M. Physiological quality of soybean seeds treated with different spray volumes. Journal of Seed Science, v.35, n.4, p.501-509, 2013. http://dx.doi.org/10.1590/S231715372013000400012

VIEIRA, E.H.; SIMONETTI, A.P.M.M. Análise fisiológica de sementes de soja submetidas a tratamento semente e diferentes períodos de armazenamento. Cultivando o Saber. v. 7, n. 4, p. 415 - 425, 2014. https://www.fag.edu.br/upload/revista/cultivando_o_ saber/54eb2cf6d73cd.pdf 